\title{
SISTEM INFORMASI INTERAKTIF PADA TRANSAKSI PULSA DENGAN MENGGUNAKAN SMS GATEWAY
}

\author{
Anton Setiawan Honggowibowo \\ STT Adisutjipto Yogyakarta \\ Jl. Janti Blok-R Lanud. Adisutjipto, Yogyakarta \\ anton_s_h@yahoo.com
}

\begin{abstract}
Information systems are generally used to support the viability of a business operation and management processes in an organization. To enhance the ability of information systems can be created an interactive information system, so it can provide rapid response and attractive to users. Interactive information system is more directed to the use of multimedia as a means of informing something. Multimedia is a combination of text, images, animations, sound and video. Various media are combined into a single unit of work will yield some information that has value that interactive communication is very high. The research will make a design of interactive information system on toll transaction using sms gateway. So the system can display the alarm and computer animated images on the screen when the computer is experiencing problems in the transaction pulse. In addition the system can also create video tutorial that shows step-by-step problem solving appropriate to the emergence of problems that occurred in the transaction pulse. With the information system interactive it will help the operator pulses respond quickly to any problems in the credit transaction.
\end{abstract}

Keywords: pulse, interactive information system, sms gateway

\section{PENDAHULUAN}

Sistem informasi merupakan kombinasi dari teknologi informasi dan aktivitas orang yang menggunakan teknologi itu untuk mendukung operasi dan manajemen. Sehingga sistem informasi sering digunakan untuk merujuk kepada interaksi antara orang, proses algoritma, data, dan teknologi. Yang mana orang sebagai pengguna sistem informasi akan berinteraksi dengan teknologi untuk mendukung kelangsungan usahanya.

Pemanfaatan sistem informasi secara umum hanya untuk mendukung kelangsungan suatu operasi usaha maupun proses manajemen di sebuah organisasi (Maher, 2011). Akan tetapi untuk lebih meningkatkan kemampuan dari sistem tersebut dapat di buat sebuah sistem informasi yang interaktif, sehingga dapat memberikan respon yang cepat dan menarik bagi penggunanya. Sistem informasi yang interaktif memang mengarah kepada penggunaan multimedia sebagai sarana menginformasikan sesuatu. Multimedia merupakan kombinasi teks, gambar, animasi, suara dan video (Hasrul, 2010). 
Berbagai media tersebut bila digabungkan menjadi satu kesatuan kerja akan menghasilkan suatu informasi yang memiliki nilai komunikasi interaktif yang sangat tinggi. Informasi yang dihasilkan memiliki komunikasi interaktif yang tinggi artinya informasi bukan hanya dapat dilihat sebagai hasil cetakan melainkan dapat didengar, membentuk simulasi dan animasi yang dapat membangkitkan selera dan memiliki nilai seni grafis yang tinggi dalam penyajiannya.

Salah satu penerapan dari sistem informasi interaktif yaitu pada sistem server transaksi pulsa, baik itu pulsa secara fisik maupun pulsa elektronik. Penerapan multimedia yang berupa suara maupun gambar diharapkan dapat membantu pihak pengelola server atau operator server dalam mengawasi layar monitor dari server pulsa tersebut. Lebih lagi apabila server terdiri dari komputer dalam jumlah yang banyak, maka diharapkan multimedia dalam wujud sistem informasi yang interaktif akan sangat diperlukan dalam memberikan respon yang cepat dan menarik bagi penggunanya.

Pada transaksi pulsa, khususnya transaksi pulsa elektronik, biasanya perusahaaan penyedia server pulsa mempunyai banyak sekali reseller atau agen penjual pulsa atau counter handphone (HP) yang menjual pulsa langsung ke konsumen. Sementara para reseller akan mengambil pulsa ke server melalui Short Message Service (SMS) dengan format tertentu ke salah satu nomer HP yang diberikan oleh pihak server dan pihak server setelah menerima sms permintaan pulsa dari reseller akan mengirimkannya kembali permintaaan tersebut ke operator penyedia pulsa atau distributor dan setelah mendapatkan jawaban dari distributor tentang status sukses atau gagal pengisian pulsa tersebut, maka pihak server akan mengirimkan balasan yang berupa sms kembali ke reseller-nya (Eva, 2013). Sehingga reseller juga mengetahui status pengisian pulsanya apakah sukses atau gagal.

Server pulsa dapat terdiri dari banyak komputer yang menangani proses berbeda-beda ke distributor yang berlainan sehingga membutuhkan pengawasan dari operator untuk menangani apabila ada permasalahan pada waktu transaksi pulsa berlangsung. Oleh karena itu pada penelitian ini akan membuat rancangan mengenai sistem informasi yang interaktif pada kasus transaksi pulsa yang menggunakan sms gateway sebagai media perantaranya. Sehingga diharapkan dengan adanya sistem informasi interakif tersebut pihak operator server pulsa dapat terbantu dalam menangani permasalahan saat transaksi pulsa dengan banyaknya 
transaksi yang bisa mencapai ribuan transaksi dalam tiap harinya.

\section{METODE PENELITIAN}

Short Message Service (SMS) merupakan aplikasi ponsel yang menyediakan layanan untuk mengirim dan menerima pesan pendek berupa huruf dan angka. Aplikasi ini hanya terbatas pada pengirim dan penerima data berupa teks dengan maksimal 140 bytes data (Sunardi, 2009).

Dalam sistem SMS, mekanisme utama yang dilakukan mengirimkan short message dari satu terminal pelanggan ke terminal yang lain. Hal ini dapat dilakukan berkat adanya sebuah entitas dalam sistem SMS yang bernama Short Message Service Center (SMSC), sebuah perangkat yang melakukan tugas store and forward trafik short message (Veena, 2012). Didalamnya termasuk penentuan atau pencarian rule tujuan akhir dari short message. Sebuah SMSC biasanya didesain untuk dapat menangani short message dari berbagai sumber seperti Voice mail system (VMS), web-based messaging, Email Integration, External Short Messaging Entities (ESME). Dalam interkoneksi dengan entitas dalam jaringan komunikasi wireless seperti Home Location Register (HLR) dan Mobile Switching Center (MSC), SMSC biasanya selalu menggunakan Signal Transfer Point (STP).
Layanan SMS merupakan sebuah layanan yang bersifat nonreal time dimana sebuah short message dapat di submit ke suatu tujuan, tidak peduli apakah tujuan itu aktif atau tidak. Bila dideteksi bahwa tujuan tidak aktif, maka sistem akan menunda pengiriman ke tujuan hingga tujuan aktif kembali. Pada dasarnya sistem SMS akan menjamin delivery dari suatu short message hingga sampai ke tujuan. Kegagalan pengiriman yang bersifat sementara seperti tujuan tidak aktif akan selalu teridentifikasi sehingga pengiriman ulang short message akan selalu dilakukan kecuali bila diberlakukan aturan bahwa short message yang telah melampaui batas waktu tertentu harus dihapus dan dinyatakan gagal.

SMS point-to-point menyediakan mekanisme untuk mengirimkan pesan pendek (short message) ke dan dari piranti bergerak (Oludare, 2013). Layanan ini menggunakan SMSC yang bertindak sebagai sistem simpan dan teruskan (store and forward) untuk pesan pendek. Ada beberapa karakteristik pesan SMS yang penting yakni:

1. Pesan SMS dijamin sampai atau tidak sama sekali, selayaknya email, sehingga jika terjadi kegagalan sistem, time-out, atau hal lain yang menyebabkan pesan SMS tidak diterima, akan diberikan informasi 
(report) yang menyatakan pesan SMS gagal dikirim.

2. Berbeda dengan fungsi call (pemanggilan), sekalipun saat mengirimkan SMS ponsel tujuan tidak aktif, bukan berarti pengiriman SMS akan gagal. Namun SMS akan masuk ke antrian dulu selama belum memasuki waktu time-out, SMS akan segera dikirimkan jika ponsel sudah aktif.

SMSC juga dapat digunakan untuk memberikan data nirkabel yang pendek. Data nirkabel ini dapat berupa layanan interaktif di mana panggilan suara juga terlibat.

SMS juga menyediakan time stamp yang menyatakan waktu pengiriman pesan ke SMSC dan memberikan suatu petunjuk pada handset mengenai masih ada atau tidaknya pesan yang akan dikirim atau banyaknya pesan tambahan yang akan dikirim.

\section{Model Komunikasi Aplikasi}

Kegunaan dasar dari sistem komunikasi adalah menjalankan pertukaran data antara 2 pihak. Berikut ini adalah elemen-elemen kunci model tersebut :

1. Source : alat ini membangkitkan data, sehingga dapat ditransmisikan, contoh telepon dan PC (Personal Computer).

2. Transmitter : biasanya data yang dibangkitkan dari sistem sumber tidak ditransmisikan secara langsung dalam bentuk aslinya. Sebuah transmitter cukup memindah dan menandai informasi dengan cara yang sama seperti menghasilkan sinyalsinyal elektromagnetik yang dapat ditransmisikan melewati beberapa transmisi berurutan.

3. Transmission System : berupa jalur transmisi tunggal atau jaringan kompleks yang menghubungkan antara sumber dengan destination .

4. Receiver : receiver menerima sinyal dari sistem transmisi dan menggabungkannya ke dalam bentuk tertentu yang dapat ditangkap oleh tujuan.

5. Destination : menangkap data yang dihasilkan oleh receiver.

Dari kelima elemen kunci tersebut, dapat digambarkan sebuah model sistem komunikasi sebagai berikut:

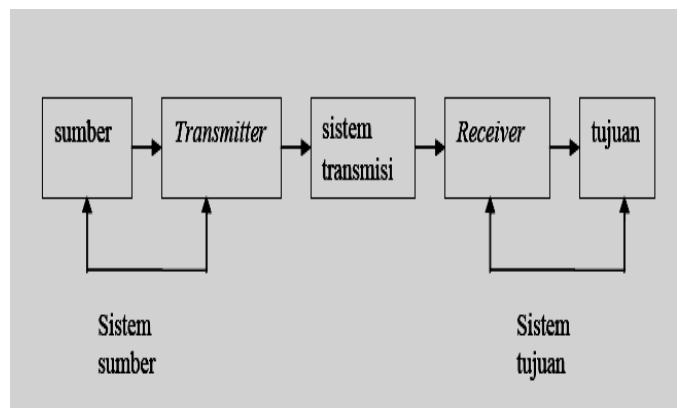

Gambar 1. Model Komunikasi Aplikasi

Perangkat input dan transmitter merupakan komponen dari suatu PC yang berguna untuk mengirim suatu pesan ke user yang lain. User mengaktifkan program di dalam PC dan 
memasukkan pesan melalui keyboard (perangkat input). String karakter Bearing ditahan didalam memori utama yang dapat dilihat dari rangkaian bit di dalam memori. PC dihubungkan dengan beberapa media transmisi, misalnya sebuah local network atau jaringan telepon, lewat suatu perangkat I/O (transmiter), dalam hal ini berupa local network transceiver atau modem. Data yang masuk dikirim ke transmitter sebagai rangkaian dari perubahan tegangan yang menunjukkan bit-bit pada communication bus atau kabel. Transmitter dihubungkan secara langsung ke media dan merubah aliran yang masuk menjadi sinyal yang mampu untuk ditransmisikan.

Sinyal yang ditransmisikan yang diserahkan ke media menjadi subyek untuk sejumlah gangguan sebelum mencapai receiver. Jadi, sinyal yang diterima dapat berbeda dari sinyal yang ditransmisikan. Receiver akan berupaya menganalisis keaslian sinyal yang terima dan menghasilkan rangkaian bit. Bit-bit ini dikirim ke komputer output, dimana bit-bit tersebut secara singkat ditahan di dalam memori sebagai informasi yang keluar. Data-data ini kemudian diberikan kepada user melalui suatu perangkat output, seperti printer atau layar. Pesan atau message sebagaimana yang dilihat oleh user biasanya merupakan salinan dari pesan aslinya atau informasi yang masuk.

Pada media transmisi, banyak sekali media yang digunakan, pada pola sistem terminal antara PC dengan ponsel, biasanya menggunakan kabel data seperti DKU 2, DKU 5, yang digunakan seri ponsel Nokia, sedangkan untuk merek ponsel lain bisa menggunakan Kabel DB12, yang merupakan satu paket kabel data ponsel, yang langsung bisa dihubungkan dengan COM 1 atau COM yang lainnya.

\section{HASIL DAN PEMBAHASAN}

Perancangan sistem informasi interaktif pada transaksi pulsa dengan menggunakan sms gateway diharapkan dapat membantu operator pulsa menangani permasalahan yang banyak dari tiap-tiap komputer. Perancangan yang akan dibuat dimulai dari perancangan tabel basis data, ERD dan perancangan form aplikasi sistem informasi. 


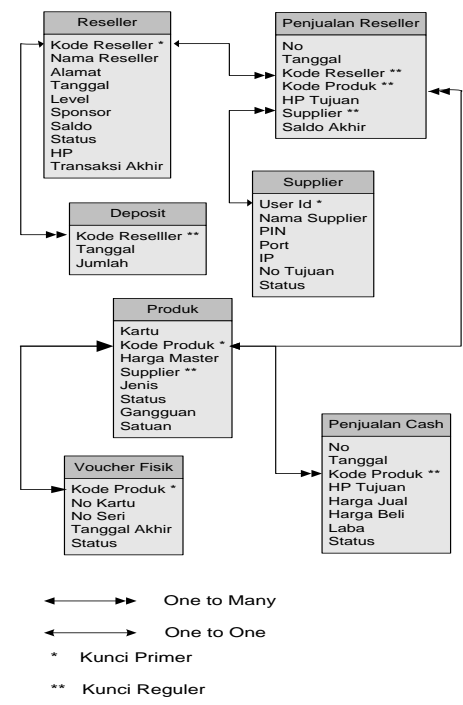

Gambar 2. ER Diagram

Skema ini menggambarkan bagaimana proses interaksi (aliran informasi) antara user dengan aplikasi sistem informasi dapat terjadi. Cara kerja keselurahan sistem adalah sebagai berikut :

1. Konsumen menemui customer service untuk melakukan transaksi atau menjadi downline

2. Customer service mencatat semua kegaiatan transaksi baik itu transaksi penjualan pulsa ataupun anggota downline yang menjadi Reseller pulsa

3. Customer service mencatat nomer ponsel, alamat, dan jenis deposit pulsa downline jika konsumen ingin menjadi downline.

4. Customer service memasukkan nomor ponsel customer, dan jenis pulsa yang akan dibeli oleh konsumen.

5. Konsumen akan menerima SMS sebagai bukti trasaksi sudah terkirim.
6. Konsumen membayar sesuai dengan nominal dan harga pulsa.

Setelah proses perancangan arsitektur sistem selesai maka dapat mulai menyusun suatu perancangan terhadap program aplikasi yang akan diperlukan untuk pengoperasian. Berikut ini adalah algoritma yang disajikan dalam bentuk flowchart, yaitu seperti yang terlihat pada gambar 3.

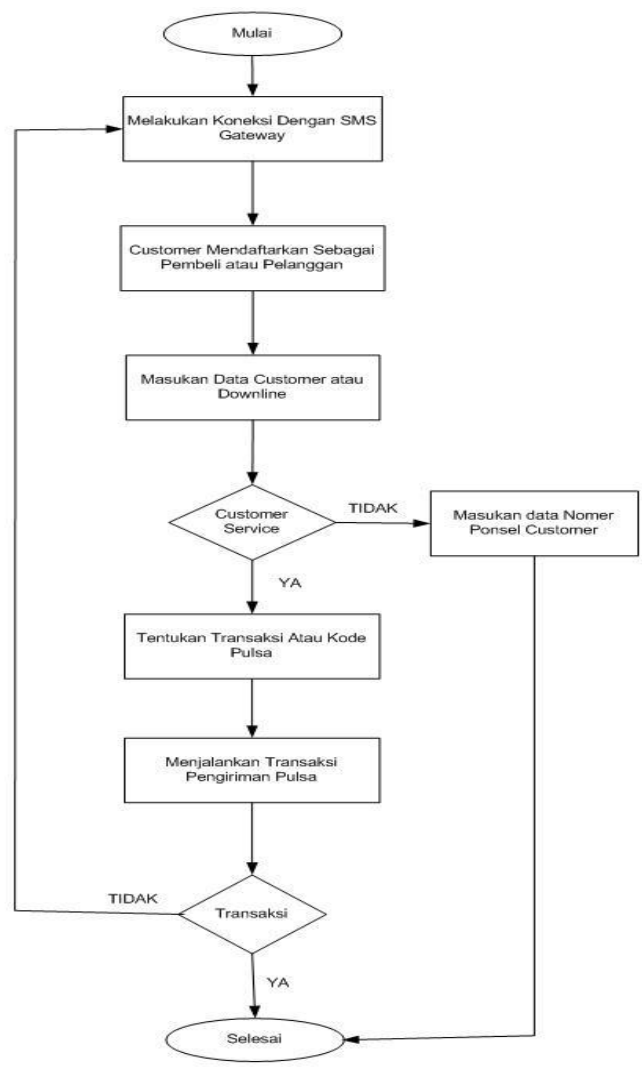

Gambar 3. Flow Chart Aplikasi Transaksi Pulsa

Dari diagram flow chart tersebut, setelah program mulai dijalankan, maka customer service akan mencatat customer sebagai pembeli atau downline, setelah 
itu program akan melakukan koneksi ponsel dengan SMS Gateway. Setelah itu, program akan menjalankan pengirim pesan pada SMS Gateway, lalu program akan memerintahkan SMS Gateway untuk meyampaikan pesan ke SMSC, lalu kembali melakukan koneksi dengan SMS Gateway untuk transaksi penjualan pulsa. Program akan melakukan query basis data sesuai dengan isi SMS yang diterima.

Perancangan tampilan untuk sistem informasi interaktif pada transaksi pulsa menggunakan sms gateway dimulai dari form login yang berisi user id dan password dari pengguna sistem. Setelah berhasil masuk kedalam sistem maka tampilan pertama yang akan muncul adalah menu pilihan yang menampilkan berbagai shortcuts yang akan menuju ke form yang lain sesuai dengan shortcuts tersebut.

Apabila dipilih salah satu shortcuts, misalkan data reseller maka aplikasi akan menampilkan form data reseller yang berisi identitas dari reseller pulsa. Reseller pulsa adalah orang atau pemilik counter pulsa yang mengambil pulsa di server ini dan akan menjualnya kepada konsumen di counter masing-masing.

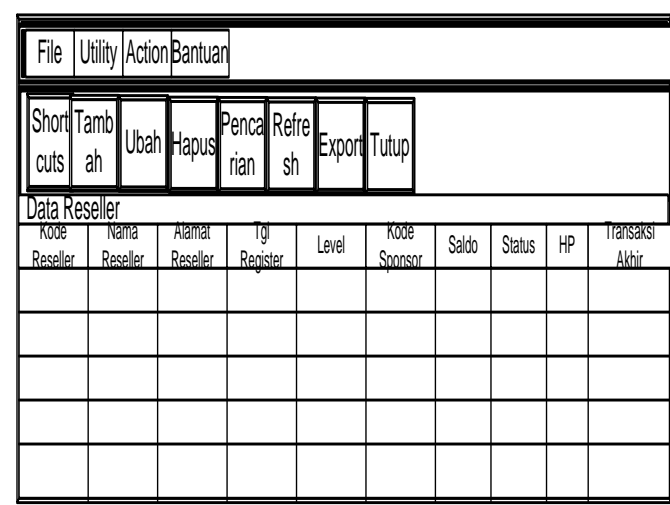

Gambar 4. Data Reseller

Di dalam form data reseller, disamping tombol shortcuts terdapat banyak tombol yang mendukung untuk pengolahan data reseller, seperti untuk menambah data, mengubah data, menghapus data reseller dan juga pencarian data. Sedangkan tombol export digunakan untuk mengirimkan data di dalam aplikasi ini kedalam bentuk file excell. Identitas dari reseller yang dapat dimasukkan adalah kode reseller, nama, alamat, tanggal mulai bergabung, level sponsornya, saldo terakhir, statusnya apakah masih aktif atau sudah tidak aktif menjadi reseller, nomer HP yang digunakan untuk transaksi pulsa, dan juga tanggal transaksi pulsa terakhir.

Shortcuts yang lain adalah data supplier yang berisi identitas dari distributor penyedia pulsa. 


\begin{tabular}{|c|c|c|c|c|c|c|c|}
\hline \multicolumn{8}{|c|}{\begin{tabular}{|l|l|l|} 
File & Utility & Action Bantuan \\
\end{tabular}} \\
\hline $\begin{array}{l}\text { Short } \\
\text { cuts }\end{array}$ & mban Uba & Hapus & ianca & $\begin{array}{c}\text { Refre } \\
\text { sh }\end{array}$ & Tutur & & \\
\hline \multicolumn{8}{|c|}{ Jata Supplier } \\
\hline Nama & User ID & PIN & Port & & IP & No Tujuan & Status \\
\hline & & & & & & & \\
\hline & & & & & & & \\
\hline & & & & & & & \\
\hline & & & & & & & \\
\hline & & & & & & & \\
\hline
\end{tabular}

Gambar 5. Data Supplier

Pada form data supplier tersedia fasilitas untuk tambah data, ubah data, hapus data dan pencarian data. Sedangkan data supplier yang dapat dimasukkan adalah nama supplier, user id yang diberikan oleh supplier, nomer pin yang akan digunakan untuk melakukan transaksi pengambilan pulsa ke supplier tertentu, port komputer yang digunakan untuk transaksi, alamat IP komputer supplier yang akan dituju, status dari supplier apakah masih aktif atau sudah tidak aktif untuk pengambilan pulsa.

Form selanjutnya adalah tentang data produk voucher pulsa yang akan dijual. Pada form data produk tersedia fasilitas untuk tambah data, ubah data, hapus data, pencarian data, export ke file excell. Isi dari data produk antara lain, yaitu jenis kartu sim card. Kode produk adalah kode yang akan digunakan oleh reseller untuk transaksi pulsa. Harga master adalah harga jual voucher pulsa. Supplier di data produk adalah sebagai penunjuk bahwa produk tersebut diperoleh dari supplier tertentu. Jenis terdiri dari dua yaitu voucher elektronik dan voucher fisik. Status menyatakan produk tersebut sedang kosong atau sedang ada stoknya. Gangguan menunjukkan apakah produk tersebut sedang mengalami gangguan operator. Satuan terdiri dari dua, yaitu stok bila produk tersebut bersumber dari stok di supplier dan saldo bila produk tersebut dari saldo supplier.

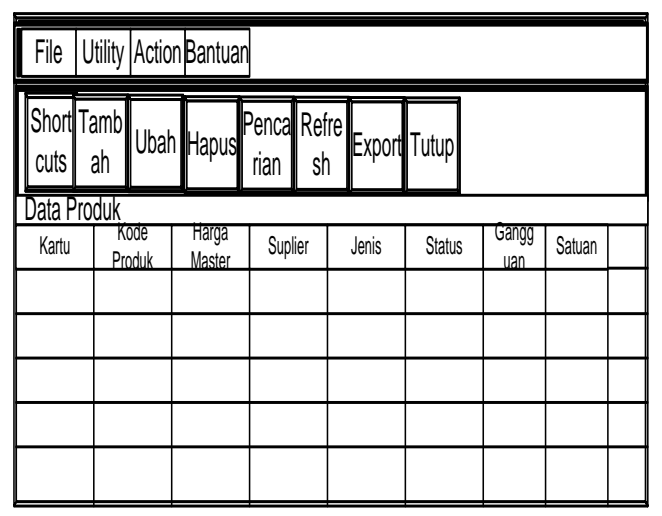

\section{Gambar 6. Data Produk}

Setelah semua data terisi lengkap maka untuk melakukan transaksi pulsa dapat dibedakan menjadi dua, yaitu untuk transaksi pulsa dari reseller dan transaksi pulsa secara langsung ke konsumen.

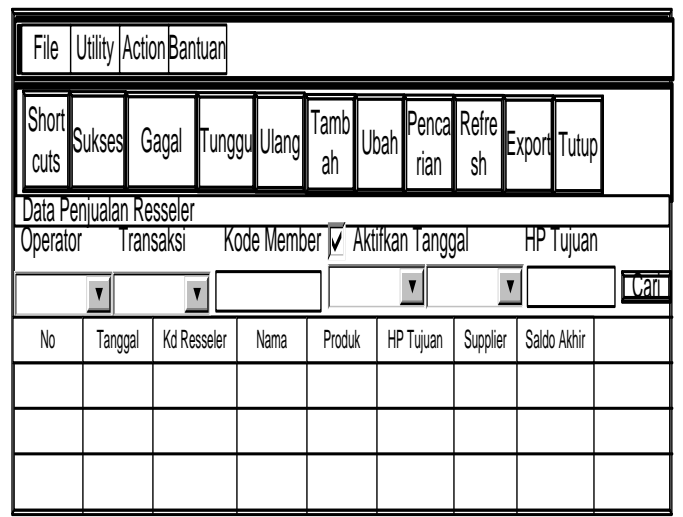

Gambar 7. Data Penjualan Reseller 
Untuk penjualan reseller, maka apabila reseller mengirimkan sms dengan format tertentu ke no ponsel server maka sms tersebut akan di simpan dan di proses ke dalam form data penjualan reseller. Sehingga di form tersebut akan berisi nomer transaksi yang otomatis bertambah, tanggal transaksi pulsa, kode dari reseller yang sudah terdaftar lebih dahulu sebelum dapat bertransaksi, nama reseller, kode produk pulsa yang dibeli oleh reseller, no HP yang akan diisi pulsanya oleh reseller, supplier penyedia voucher tersebut, saldo akhir dari reseller. Disamping tombol shortcuts terdapat tombol sukses untuk menyukseskan transaksi pulsa, tombol gagal apabila transaksi tersebut gagal, tombol tunggu untuk mengubah status sukses atau gagal menjadi status tunggu yang nantinya akan dapat diproses kembali dengan menggunakan tombol ulang untuk mengulang transaksi sampai di ketahui sukses atau gagal.

Didalam form data penjualan reseller inilah penerapan dari sistem informasi interaktif dapat dilakukan dengan menyertakan nada semacam alarm. Sehingga apabila ada sms masuk dari reseller yang ingin transaksi pulsa maka sistem ini akan memunculkan nada alarm sehingga operator pulsa dapat mengetahui bahwa ada transaksi masuk. Walaupun secara otomatis sistem akan mengirim transaksi pembelian dari reseller tersebut

ke supplier, akan tetapi dengan adanya alarm tersebut akan membantu operator mengetahui adanya transaksi dan bila terjadi kemacetan maka operator dapat mengambil alih sistem dengan melakukan transaksi secara manual untuk mempercepat proses transaksi pulsa sampai diketahui hasil sukses maupun gagalnya.

Demikian juga apabila transaksinya berstatus tunggu/ pending melebihi batas waktu yang ditetapkan, misalkan lebih dari lima menit, maka akan muncul alarm yang berbeda sehingga operator akan mengetahui dan dapat memproses transaksi tersebut sehingga pengiriman pulsa menjadi lebih cepat. Status tunggu dapat terjadi apabila terjadi down pada koneksi internet, ponsel pengirim yang mati atau tidak ada sinyal, gangguan operator atau status kosong dari suatu supplier. Biasanya status tunggu ini yang membuat reseller yang tidak sabar menunggu karena lamanya pulsa yang masuk ke ponsel konsumen akan menghubungi pihak server menanyakan status transaksi pada nomer tersebut. Selain muncul alarm dapat juga dimunculkan gambar animasi dilayar komputer server tersebut yang menarik bagi operator untuk mengamatinya. Hal ini digunakan pada komputer server dengan jumlah komputer yang lebih dari satu, karena bunyi alarm akan sama 
untuk setiap komputer dan tidak mungkin operator bisa menghapal berbagai bunyi alarm apabila tiap komputer berbeda bunyinya untuk mengetahui komputer mana yang mengalami masalah transaksi pulsanya. Sehingga dengan memunculkan gambar animasi di layar komputer dan sekaligus alarm akan menarik operator hanya mengamati ke layar komputer yang menampilkan animasi gambar tersebut. Selain itu dapat juga di munculkan video cara penanganan untuk suatu permasalah yang muncul setelah alarm berbunyi, sehingga memudahkan operator pulsa menyelesaikan masalah dengan cepat dan tepat. Karena dengan makin cepatnya pulsa dapat terisi/ masuk ke pembeli maka akan meningkatkan kepercayaan reseller terhadap server tersebut.

Untuk reseller yang tergabung pada server ini akan melakukan deposit uang ke server yang mana nanti uang deposit tersebut akan berkurang jumlahnya apabila terjadi transaksi pulsa yang dilakukan oleh reseller tersebut. Sehingga perlu disediakan form yang dapat melihat berapa banyak saldo tersisa dari tiap-tiap reseller.

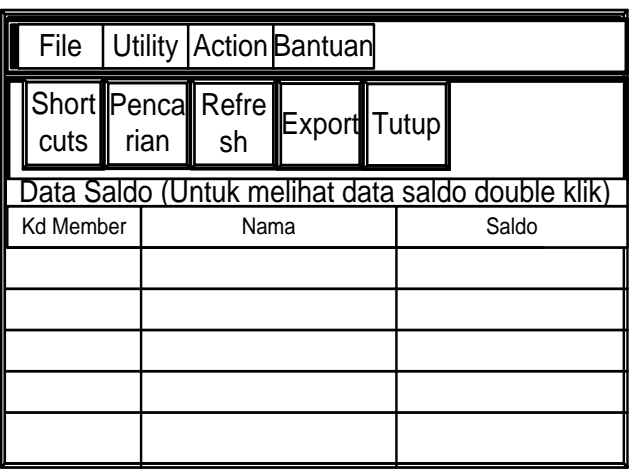

Gambar 8. Data Saldo

Pada form data saldo terdapat tampilan data kode member atau kode reseller, nama reseller dan sisa saldo yang dimiliki oleh reseller tersebut. Sedangkan untuk menyimpan perubahan deposit dari reseller disediakan form data deposit.

\begin{tabular}{|c|c|c|c|c|c|c|}
\hline \multicolumn{7}{|c|}{\begin{tabular}{|l|l|l|} 
File & Utility & Action Bantuan \\
\end{tabular}} \\
\hline $\begin{array}{c}\text { Shortc } \\
\text { uts }\end{array}$ & \begin{tabular}{c||l} 
Tamb \\
ah
\end{tabular} & \begin{tabular}{|c|} 
Penca \\
rian
\end{tabular} & \begin{tabular}{l||l} 
Sefre & \\
sh & Exp \\
\end{tabular} & orf Tutup & & \\
\hline$\overline{\overline{D a t a D}}$ & $\frac{\text { Oosit }}{\text { an Tanggal }}$ & & & & & \\
\hline & $\nabla S / D$ & & $\nabla$ & पदा & & \\
\hline Id Tix & \begin{tabular}{c|} 
Kode \\
Reseller \\
\end{tabular} & $\begin{array}{l}\text { Nama } \\
\text { Reseller }\end{array}$ & Tgl Input & Jumlah & Saldo Awal & $\begin{array}{l}\text { Saldo } \\
\text { Akhir }\end{array}$ \\
\hline & & & & & & \\
\hline & & & & & & \\
\hline & & & & & & \\
\hline
\end{tabular}

Gambar 9. Data Deposit

Form data deposit berisi data tentang id transaksi deposit, kode reseller yang melakukan deposit uang, nama reseller, tanggal input data deposit, jumlah uang yang di depositkan, saldo awal sebelum dilakukan deposit uang dan yang terakhir adalah saldo akhir setelah dilakukan deposit uang.

SMS dari reseller yang kompline pulsa, mungkin karena pulsanya belum 
masuk atau lama masuknya atau reseller yang ingin mengetahui informasi tertentu dan menanyakan ke server dapat ditangani di form data sms info.

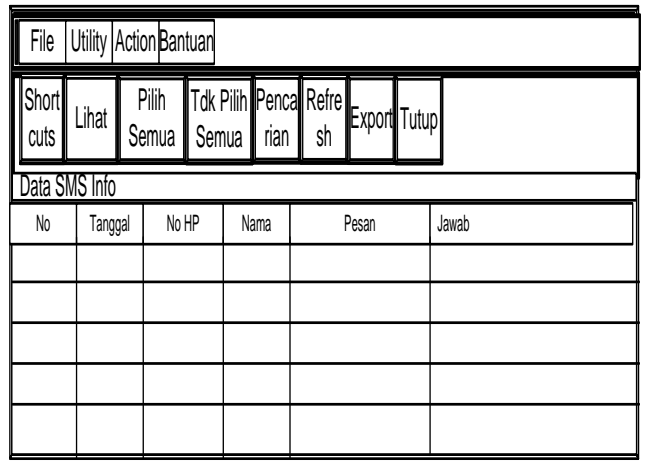

\section{Gambar 10. Data SMS Info}

Pada form data sms info menampilkan no transaksi, tanggal sms masuk, no HP reseller yang mengirim sms, nama reseller, isi pesan yang di kirim oleh reseller dan jawaban yang diberikan dari pihak operator ke reseller tersebut.

Pada form data sms info ini juga dapat diterapkan sistem informasi interaktif seperti halnya pada penjualan reseller dengan memberikan alarm apabila ada sms masuk, gambar animasi dilayar komputer yang menandakan adanya sms yang masuk dari reseller, dan berbagai pilihan jawaban yang dapat diberikan sebagai jawaban atas pertanyaan dari reseller.

Aplikasi sms gateway yang digunakan untuk menghubungkan HP dengan sistem adalah suatu aplikasi yang dapat menerima sms masuk dari reseller dan mencatat tanggal beserta dengan no HP pengirim sms dan juga dapat mengirim sms ke reseller dan mencatat nomer HP tujuan beserta dengan tanggal transaksinya.

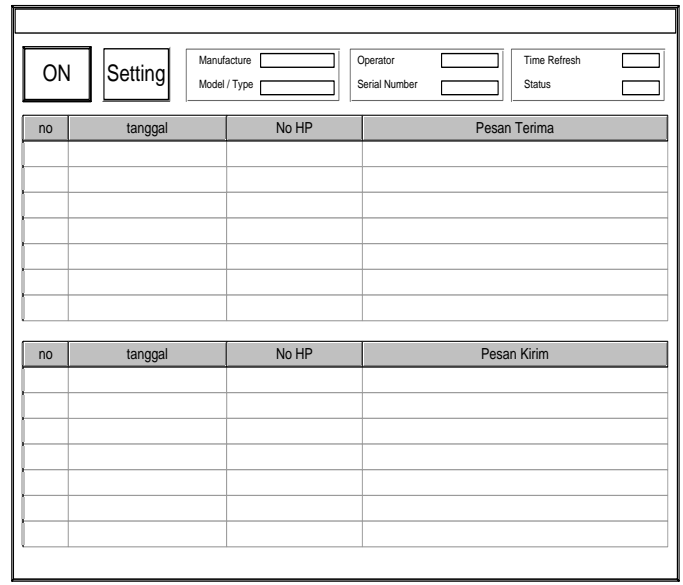

Gambar 11. SMS Gateway

Perancangan sistem informasi interaktif pada transaksi pulsa berbasis sms gateway ini dinilai telah dapat memenuhi kebutuhan untuk menangani transaksi pulsa yang jumlahnya bisa mencapai ribuan transaksi tiap harinya. Kemampuan interaktif dari sistem informasi ini dapat membantu pihak operator server dalam menangani banyaknya komputer yang menangani transaksi pulsa dengan menampilkan suara alarm atau animasi gambar di layar komputer yang ada masalah dan juga menampilkan video cara-cara penyelesaian masalah yang sering terjadi. Sehingga dengan kemampuan interaktif tersebut maka operator dapat merespon dengan cepat dan segera menangani permasalahan yang ada. 


\section{KESIMPULAN}

Dari hasil penelitian, perancangan dan implementasi yang telah dilakukan dapat ditarik kesimpulan sebagai berikut :

1. Sistem yang telah dibuat memiliki kemampuan menangani transaksi pulsa dengan menggunakan sms gateway.

2. Sistem akan memberikan peringatan berupa bunyi alarm apabila ada suatu permasalahan dengan komputer pulsa.

3. Sistem dapat menampilkan gambar animasi di layar komputer yang sedang mengalami masalah.

4. Sistem dapat menampilkan video tutorial yang tepat dengan masalah yang muncul pada saat transaksi pulsa berjalan.

5. Sistem informasi yang interaktif dapat membantu operator sehingga lebih cepat mengetahui adanya permasalahan di komputer pulsa.

\section{DAFTAR PUSTAKA}

Maher Abdel-qader, Ahmad Al-Jaber, Alaa Al-Hamami, 2011, Using Short Message Service (SMS) to Support Business Continuity, World of Computer Science and Information Technology Journal, Vol. 1, No. 2, hal 34-38.

Hasrul, 2010, Langkah - langkah Pengembangan Pembelajaran Multimedia Interaktif, Jurnal Medtek, Volume 2, No. 1.

Eva Yulianti, Tauvan Rusyiatno, 2013, Rekayasa Perangkat Lunak Penjualan Pulsa Elektric Berbasis
SMS Menggunakan Visual Basic 6.0, Jurnal TeknoIf, Vol. 1, No. 1, hal 20-25.

Sunardi, Hari Murti, Hersatoto Listiyono, 2009, Aplikasi SMS Gateway, Jurnal Teknologi Informasi Dinamik, Volume XIV, No. 1, hal : 30-34.

Veena K.Katankar et. Al, 2010, Short Message Service Using SMS Gateway, International Journal on Computer Science and Engineering, Vol. 02, No. 04, hal 1487-1491.

Oludare Olaleye, Ayodele Olaniyan, Olalekan Eboda, Adeleke Awolere, 2013, SMS-Based Event Notification System, Journal of Information Engineering and Applications, Vol.3, No. 10, hal 55-62. 